\title{
Profile of traumatic brain injury (TBI) in relation with maxillofacial and thoracic injury Dr. Hasan Sadikin General Hospital, Bandung
}

\author{
Padmini Laxmi Pathmanathan, ${ }^{1 *}$ Gibran Tristan Alpharian, ${ }^{2}$ Agung Budi Sutiono ${ }^{3}$ \\ ${ }^{1}$ Faculty of Medicine, Universitas Padjadjaran, ${ }^{2}$ Department of Orthopedic and Traumatology \\ Faculty of Medicine, Universitas Padjajaran/Dr. Hasan Sadikin General Hospital Bandung, \\ ${ }^{3}$ Department of Neurosurgery, Faculty of Medicine, Universitas Padjadjaran/ Dr. Hasan \\ Sadikin General Hospital, Bandung, Indonesia.
}

DOI: http://dx.doi.org/10.19106/JMedScie/005003201808

\section{ABSTRACT}

Traumatic brain injury (TBI) has a relation with concomitant injuries, which are mostly maxillofacial and thoracic injury. This study aimed to know which injury was common in TBI patients and the difference in the severity of TBI when patients were associated with one or both types of injuries. This was a descriptive retrospective study. The data used was medical records from Department of Neurosurgery, Dr. Hasan Sadikin General Hospital, Bandung, Indonesia from the period of August 2015 to July 2016. Total sampling method was used in this study. The variables were patients with TBI, maxillofacial injury, thoracic injury, accident related mechanism and non-accident related mechanism and the Glasgow Coma Score (GCS). The total cases for this study were 47 patients. The highest case was males with 37 cases and 10 for females. Accident related trauma had 23 cases whereas non accident related trauma had 24 cases. The total cases of maxillofacial injury were 32 , thoracic were 6 cases whereby for both injuries were 9 cases. Patients with mild TBI were 28 cases, moderate TBI were 13 cases, and severe TBI had 6 cases in total. The rate of TBI was higher in single injury which was the maxillofacial injury. However, the thoracic and both injuries combined had higher severity of TBI compared to maxillofacial injury.

\section{ABSTRAK}

Cedera otak traumatika (COT) dapat disertai dengan cedera maksilofasial dan cedera thoraks. Penelitian ini bertujuan untuk mengetahui pasien dengan COT yang memiliki keparahan yang lebih tinggi dari cedera multiple dan perbedaan dalam keparahan COT ketika pasien dikaitkan dengan satu jenis cedera atau kedua cedera. Penelitian ini merupakan penelitian deskriptif retrospektif. Data yang digunakan adalah rekam medis pasien dari Departemen Bedah Saraf, Rumah Sakit Hasan Sadikin dari periode bulan Agustus 2015 hingga Juli 2016. Sampel diperoleh adalah sebanyak 47 pasien berdasarkan total sampling. Variabel dalam penelitian ini adalah pasien dengan cedera traumatis otak, cedera maksilofasial, cedera thoraks, mekanisme terkait dengan kecelakaan, mekanisme yang tidak terkait dengan kecelakaan dan Glasgow Coma Scale (GCS). Total kasus untuk penelitian ini adalah 47 pasien. Kasus cedera kepala terbanyak terjadi pada laki laki, yaitu 37 kasus dan 10 sisanya pada perempuan. COT akibat kecelakaan ada 23 kasus dan bukan akibat kecelakaan ada 24 kasus. Total kasus cedera maksilofasial adalah 32 dan untuk thoraks adalah 6 dan untuk jenis cedera keduanya adalah 9 kasus. Pasien dengan cedera COT ringan ada 28, kasus COT sedang ada 13 dan COT berat memiliki 6 kasus. Kasus COT kebanyakannya terjadi pada kasus cedera maksilofasial. Namun, jika cedera toraks dan dua cedera terkombinasi maka tingkat keparahan COT menjadi lebih tinggi dibandingkan dengan cedera maksilofasial.

Keywords: traumatic brain injury -maxillofacial - thoracic injury - accident - Glasgow Coma Scale 


\section{INTRODUCTION}

Traumatic brain injury (TBI) have a correlation with certain types of injuries and mostly are those with multiple injuries non related to neurological problems. ${ }^{1}$ A situation exists when the physical loads overload the brain is known as TBI. It means that there is an accident which gives an impact that causes a high level of stress that cannot be handled by the brain until it damages it in the form of brain injury. ${ }^{2}$ A study was conducted by the National Automotive Sampling System-Crashworthiness Data System and Crash Injury Research Engineering Network to investigate the injuries affecting which part of the body organs from a road accident. Th most affected body organs are the head and thorax. ${ }^{3}$

Thoracic injuries patients commonly have been linked with TBI. ${ }^{4}$ Thorax-only blast injury apparatus and a jugular-only blast injury apparatus was constructed to see if the wave from a thoracic injury would transmit to the brain and how the direct wave at the cranium causes the brain injury. ${ }^{2}$ Maxillofacial injuries are most commonly related to TBI as well. The brain is affected because its position is located near to the orbital and zygomatic areas. ${ }^{5}$ Out of 1.4 million of Americans from the year 1995 to 2001 have been diagnosed with TBI, more than one million was spotted with mild TBI with a Glasgow Coma Score (GCS) of 14 to 15 , with a score of 9 to 13 for moderate TBI and 3 to 8 for severe TBI. American Congress of Rehabilitation Medicine and The Centers for Disease Control and Prevention has defined that there is no abnormality in neuroimaging of TBI and TBI is solely diagnosed based on clinical symptoms. ${ }^{6}$ This study was conducted to evaluate TBI patients with highest rate of concomitant injuries and the difference in the severity of TBI when the cases were associated with one or both types of injuries.

\section{MATERIALS AND METHODS}

\section{Subjects}

This was a descriptive retrospective study using the medical record of patients from the Department of Neurosurgery, Dr. Hasan Sadikin General Hospital, Bandung during the period of August 1 $1^{\text {st }}, 2015$ to July $31^{\text {st }}$, 2016 who met the inclusion and exclusion criteria. Patients aged from 18 to 65 years who diagnosed with TBI associated with maxillofacial or thoracic or both injuries were involved in this study. Whereas, patients who not meet into this age criteria, or not diagnosed with TBI but have concomitant injuries or vice versa were excluded from the study. The protocol of the study has been approved by the Health Research Ethics Committee Faculty of Medicine, Universitas Padjadjaran/Dr. Hasan Sadikin General Hospital, Bandung.

\section{Data collected}

The data of patients included traumatic brain injury, maxillofacial injury, thoracic injury, accident-related mechanism and nonaccident related mechanism were gathered. The Glasgow Coma Score was calculated to classify TBI severity into mild, moderate and severe.

\section{Statistical analysis}

Data were presented as mean \pm standard deviation (SD) or frequency or percentage and the then analyzed descriptively.

\section{RESULTS}

A total of 47 patients with TBI associated with either maxillofacial, thoracic or both injuries and classified based on age and gender are presented in TABLE 1 . The highest range of age collected from the data between the age of 18 to 27 years old for both males and females. 
TABLE 1. Frequency of TBI associated with concomitant injuries based on age and gender $(n=47)$

\begin{tabular}{|c|c|c|c|c|c|c|c|c|}
\hline \multirow[t]{2}{*}{ Age (years) } & \multirow[t]{2}{*}{ Frequency } & \multirow[t]{2}{*}{ Mean $\pm \mathrm{SD}$} & \multicolumn{2}{|c|}{$\begin{array}{c}\text { TBI }+ \\
\text { Maxillofacial }\end{array}$} & \multicolumn{2}{|c|}{$\begin{array}{c}\text { TBI + } \\
\text { Thoracic }\end{array}$} & \multicolumn{2}{|c|}{$\begin{array}{c}\text { TBI + } \\
\text { Both injuries }\end{array}$} \\
\hline & & & (n) & $(\%)$ & (n) & $(\%)$ & (n) & $(\%)$ \\
\hline \multicolumn{9}{|l|}{ Male } \\
\hline - $18-27$ & 14 & & & & & & & \\
\hline - $28-37$ & 9 & & & & & & & \\
\hline - $38-47$ & 7 & $35 \pm 12.77$ & 24 & 51.1 & 6 & 12.8 & 7 & 14.9 \\
\hline - $48-57$ & 5 & & & & & & & \\
\hline - $58-67$ & 2 & & & & & & & \\
\hline \multicolumn{9}{|l|}{ Female } \\
\hline - $18-27$ & 5 & & & & & & & \\
\hline - $28-37$ & 1 & & & & & & & \\
\hline - $38-47$ & 2 & $33 \pm 14.35$ & 7 & 14.9 & 2 & 4.2 & 1 & 2.1 \\
\hline - 48-57 & 1 & & & & & & & \\
\hline - 58-67 & 1 & & & & & & & \\
\hline
\end{tabular}

Accident related trauma had 23 cases and mostly were due to motorcycle accidents. Most of them were diagnosed with TBI and maxillofacial injury. Car crash contributed to the highest TBI associated with both maxillofacial and thoracic injuries (FIGURE 1).

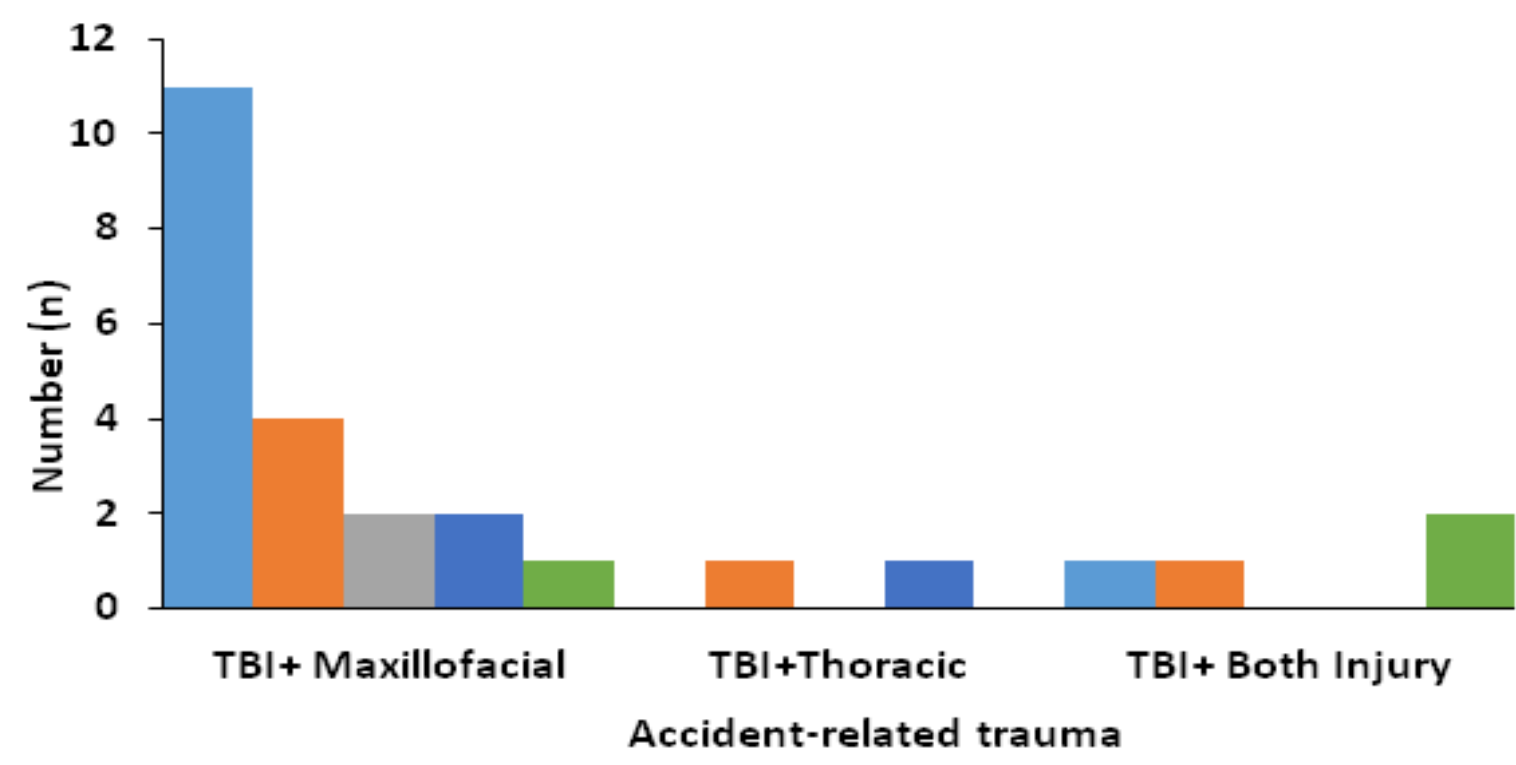

FIGURE 1. TBI associated with concomitant injury based on accident-related trauma 
On the other hand, non-accident-related trauma had 24 cases in total. There were no cases reported that sports caused traumatic brain injury in the data. Most patients were diagnosed TBI due to fall either from bike, staircase, or ladder. The mechanism of injury was unknown for 7 cases (FIGURE 2).

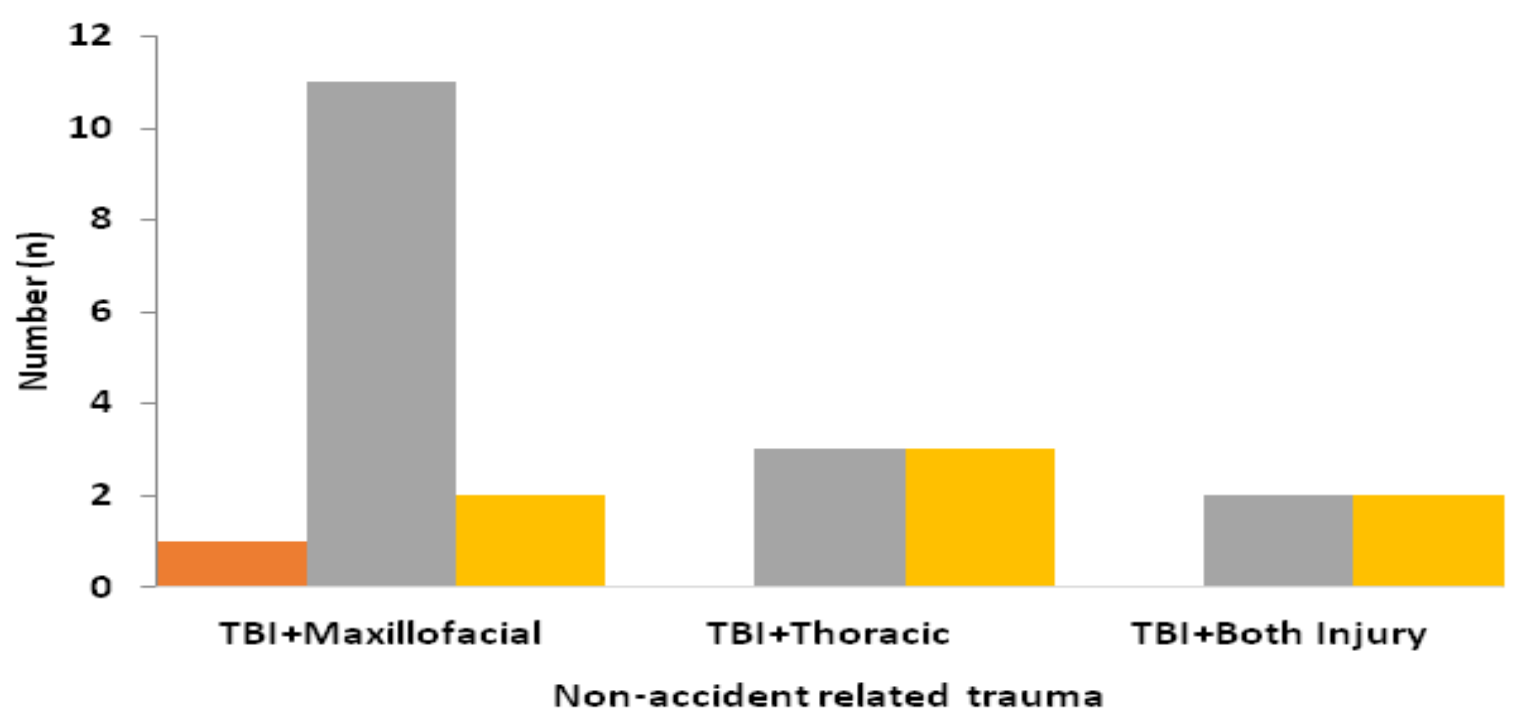

FIGURE 2. TBI associated with concomitant injury based on non-accident related trauma

Based on the previous data (TABLE 1, FIGURE 1 and 2), TBI with maxillofacial, thoracic, or both injuries can be classified into mild, moderate, or severe TBI. Most TBI patients had maxillofacial injury, (32 cases), and several patients had thoracic (6 cases) or both (9 cases) injuries (TABLE 2$)$. The highest severity of TBI evaluated based on GCS reported in the period of August 2015 to July 2016 was TBI with GCS from 14 to 15 (28 cases), whereas moderate TBI with GCS from 9 to 13 was 15 cases and severe TBI with GCS from 3 to 8 was 8 cases.

TABLE 2. Frequency of TBI with concomitant injury based on its severity evaluated by GCS

\begin{tabular}{lcccccc}
\hline \multirow{2}{*}{ Glasgow Coma Score } & \multicolumn{2}{c}{ TBI+ Maxillofacial } & \multicolumn{2}{c}{ TBI+ Thoracic } & \multicolumn{2}{c}{ TBI+ Both Injuries } \\
\cline { 2 - 7 } & $(\mathrm{n})$ & $(\%)$ & $(\mathrm{n})$ & $(\%)$ & $(\mathrm{n})$ & $(\%)$ \\
\hline Mild $(\mathrm{n}=27)$ & 21 & 44.6 & 2 & 4.3 & 5 & 10.5 \\
Moderate $(\mathrm{n}=13)$ & 9 & 19.1 & 2 & 4.3 & 2 & 4.3 \\
Severe $(\mathrm{n}=6)$ & 2 & 4.3 & 2 & 4.3 & 2 & 4.3 \\
\hline
\end{tabular}

TABLE 3 shows the percentage of each injuries based on the GCS severity cases. It is understood that TBI patients with maxillofacial injury had the highest percentage for mild TBI. However, it is demonstrated that more patients with thoracic injury and both injuries had severe TBI than patients with mild and moderate TBI. 
TABLE 3. Percentage of TBI severity based on different types of injury

\begin{tabular}{lccc}
\hline Types of injury & Mild $(\%)$ & Moderate $(\%)$ & Severe $(\%)$ \\
\hline TBI + Maxillofacial & 75.0 & 69.2 & 33.3 \\
TBI + Thoracic & 7.1 & 15.4 & 33.3 \\
TBI + Both Injuries & 17.9 & 15.4 & 33.3 \\
Total & 100.0 & 100.0 & 100 \\
\hline
\end{tabular}

Note $:($ mild, $\mathrm{n}=28$; moderate, $\mathrm{n}=13$; severe, $\mathrm{n}=6$ )

\section{DISCUSSION}

TABLE 1 shows the frequency of traumatic brain injury associated with concomitant injuries based on age and gender. It proved that males $(n=50)$, which comprised of $79 \%$ of total cases, had higher rate of concomitant injuries than females $(n=13)$, which were $21 \%$ of total cases. A study conducted in Qatar ${ }^{7}$ causes, and outcome of TBI in adolescents and young adult population in Qatar. Method. This was a retrospective review of all TBIs admitted to the trauma center between January 2008 and December 2011. Demographics, mechanism of injury, morbidity, and mortality were analyzed in different age groups. Results. A total of 1665 patients with TBI were admitted; the majority were males (92\% reported that patients who were diagnosed with TBI were mostly males. They had risk of almost four times higher than females, as most of the males in Qatar had head injury since adolescence. It was also reported that the highest age group that was diagnosed with TBI and had concomitant injury falls under the age category of 20 to 29 years ${ }^{2}$ old. Compared to this study, it happed almost under the age group of 18 to 27 years' old.

As can be seen in TABLE 2, the accidents related to motorcycles' ${ }^{2}$ are the highest, which was 9 out of 23 cases ( $39.1 \%$ ), compared to other accident-related trauma. This is in agreement with a previous study conducted by Aladelusi et al. ${ }^{8}$ where most of their patients were motorcyclists compared with other accident-related patients. In addition, only $15 \%$ of that motorcyclists wore helmet on road and this seemed to contribute to most of the maxillofacial injury. A study in the United States ${ }^{3}$ proved that car crash caused injuries in both the head and thorax as also found in this research, where 2 out of 3 cases of car crash contributed to TBI with both maxillofacial and thoracic injuries compared to individual injuries. A research conducted in Austria ${ }^{1}$ showed that for nonaccident related trauma, fall had the highest rate compared to sports related, violence, others and unknown causes of traumatic brain injury. This also occurred in this study (TABLE 3), where fall had 16 cases out of 24 cases and contributed up to $66.7 \%, 47.8 \%$ of which were maxillofacial injury. Eight cases had unknown mechanism of injury and 1 case was violence case. The previous study from Austria ${ }^{1}$ and Qatar $^{7}$ do not support this research where the accident-related trauma cases were higher than the non accidentrelated trauma cases in their respective countries, although a study from $\mathrm{USA}^{9}$ has stated that fall was their most common mechanism of injury, and hence supporting this study.

The study conducted by Meaney et al. ${ }^{10}$ reported that in public, most people with TBI were diagnosed with mild TBI. This was similar to this study. Out of 47 cases, 28 cases $(59.4 \%$ of all cases) were reported with mild TBI. Moderate TBI was seen in fewer cases (13 cases or $27.7 \%$ of all cases), and the least, 6 cases $(12.9 \%$ of all cases) were severe TBI patients. Patients with TBI associated with maxillofacial injury were the highest cases diagnosed with mild TBI. The same result has been reported in a previous 
study conducted ini Nigeria ${ }^{8}$ with $35 \%$ of all cases. However, a study performed by Arslan et al. ${ }^{11}$ reported that more patients with TBI associated with maxillofacial injury were diagnosed with severe TBI, which was 17 out of 24 cases. This could be due to the causal differences as most patients were admitted because of violence. Severe TBI patients were equally associated with maxillofacial, thoracic, or both injuries combined as there were 2 out of 6 cases for each type of injury. On the other hand, the study conducted by Veysi et al. ${ }^{12}$ reported that the severity of TBI started from moderate to severe TBI (based on severity of the thoracic injury). Therefore it is different from this study that showed an equal number of cases for each type of severity. In this study, TBI associated with both injuries (maxillofacial and thoracic injuries) was mostly diagnosed with severe TBI with $33.3 \%$ of all cases, while for mild TBI was $17.9 \%$ of all cases and moderate TBI was $15.4 \%$ of total cases. A study performed in Australia ${ }^{13}$ has mentioned that patients with TBI and concomitant injury might undergo worse TBI outcome than those diagnosed with TBI only due to the involvement of cytokine that cause the TBI pathobiology. It partially in agreement with this study, as severe TBI was the most common diagnosis and followed by mild and moderate TBI. The limitation in this study was the lack of primary data.

\section{CONCLUSION}

In conclusion, TBI can be associated with concomitant injuries. Patients are most commonly associated with either maxillofacial, thoracic, or both injuries in an accident-related or non accident-related trauma. The rate of TBI is higher in single injury which is the maxillofacial injury. However, the thoracic and both injuries combined has higher severity of TBI compared to maxillofacial injury.

\section{ACKNOWLEDGEMENT}

We would like to thank our colleagues form Department of Neurosurgery, Dr. Hasan Sadikin General Hospital, Bandung and many parties who give valuable assistance during this study.

\section{REFERENCES}

1. Leitgeb J, Mauritz W, Brazinova A, Majdan M, Wilbacher I. Impact of concomitant injuries on outcomes after traumatic brain injury. Arch Orthop Trauma Surg 2013;133(5):659-68. http://dx.doi.org/10.1007/s00402-013-1710-0

2. Simard JM, Pampori A, Keledjian K, Tosun C, Schwartzbauer G, Ivanova $\mathrm{S}$, et al. Exposure of the thorax to a sublethal blast wave causes a hydrodynamic pulse that leads to perivenular inflammation in the brain. $\mathrm{J}$ Neurotrauma 2014;31(14):1292-304. http://dx.doi.org/10.1089/neu.2013.3016

3. Yoganandan N, Arun MW, Halloway DE, Pintar FA, Maiman DJ, Szabo $\mathrm{A}$, et al. Crash characteristics and injury patterns of restrained front seat occupants in far-side impacts. Traffic Inj Prev 2014;15(Suppl 1):27-34. http://dx.doi.org/10.1080/15389588.2014.935771

4. Dai D, Yuan Q, Sun Y, Yuan F, Su Z, Ding $\mathrm{J}$, et al. Impact of thoracic injury on traumatic brain injury outcome. PLoS One 2013;8(9):e74204. http://dx.doi.org/10.1371/journal.pone.0074204

5. Ramneesh G, Gulzar G, Sanjeev U, Rajinder M, Ranabir P, Nikhil G. A retrospective audit of hundred patients of orbitozygomatic fractures with brain injury. J Clin Diagn Res 2014;8(7):4-6. http://dx.doi.org/10.7860/JCDR/2014/9465.4547

6. Blyth BJ, Bazarian JJ. Traumatic alterations in consciousness: traumatic brain injury. Emerg Med Clin North Am 2010;28(3):571-94. http://dx.doi.org/10.1016/j.emc.2010.03.003 
7. El-Matbouly M, El-Menyar A, AlThani H, Tuma M, El-Hennawy $\mathrm{H}$, Abdulrahman $\mathrm{H}$, et al. Traumatic brain injury in Qatar: age matters--insights from a 4-year observational study. Sci World J 2013;2013:354920. http://dx.doi.org/10.1155/2013/354920

8. Aladelusi T, Akinmoladun V, Olusanya A, Akadiri O, Fasola A. Analysis of road traffic crashes-related maxillofacial injuries severity and concomitant injuries in 201 patients seen at the $\mathrm{UCH}$, Ibadan. Craniomaxillofac Trauma Reconstr 2014;7(4):284-9. http://dx.doi.org/10.1055/s-0034-1378183

9. Stead LG, Bodhit AN, Patel PS, Daneshvar Y, Peters KR, Mazzuoccolo $\mathrm{A}$, et al. TBI surveillance using the common data elements for traumatic brain injury: a population study. Int J Emerg Med 2013;6(1):5. http://dx.doi.org/10.1186/1865-1380-6-5

10. Meaney DF, Morrison B, Dale Bass C. The mechanics of traumatic brain injury: a review of what we know and what we need to know for reducing its societal burden. J Biomech Eng2014;136(2):210081.

http://dx.doi.org/10.1115/1.4026364

11. Arslan ED, Solakoglu AG, Komut E, Kavalci C, Yilmaz F, Karakilic E, et al. Assessment of maxillofacial trauma in emergency department. World J Emerg Surg 2014;9(1):13.

http://dx.doi.org/10.1186/1749-7922-9-13

12. Veysi VT, Nikolaou VS, Paliobeis C, Efstathopoulos N, Giannoudis PV. Prevalence of chest trauma, associated injuries and mortality: a level I trauma centre experience. Int Orthop 2009;33(5):1425-33. http://dx.doi.org/10.1007/s00264-009-0746-9

13. McDonald SJ, Sun M, Agoston DV, Shultz SR. The effect of concomitant peripheral injury on traumatic brain injury pathobiology and outcome. J Neuroinflammation 2016; 13(1):90. http://dx.doi.org/10.1186/s12974-016-0555-1 